\title{
INVENTORY OF BIOLOGICAL INVESTIGATIONS RELATED TO STREAM WATER QUALITY IN THE SOUTH PLATTE RIVER BASIN, COLORADO, NEBRASKA, AND WYOMING, 1891-1994
}

by Cathy M. Tate and Jorge R. Ortiz-Zayas

U.S. GEOLOGICAL SURVEY

Open-File Report 95-379

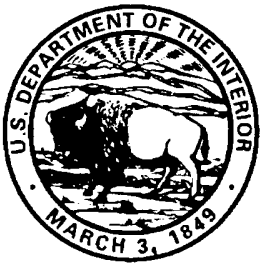




\section{U.S. DEPARTMENT OF THE INTERIOR BRUCE BABBITT, Secretary}

U.S. GEOLOGICAL SURVEY

Gordon P. Eaton, Director

The use of trade, product, industry, or firm names is for descriptive purposes only and does not imply endorsement by the U.S. Government.

For additional information write to:

District Chief

U.S. Geological Survey

Box 25046, MS 415

Denver Federal Center

Denver, CO 80225
Copies of this report can be purchased from:

U.S. Geological Survey

Earth Science Information Center

Open-File Reports Section

Box 25286, MS 517

Denver Federal Center

Denver, CO 80225 


\section{CONTENTS}

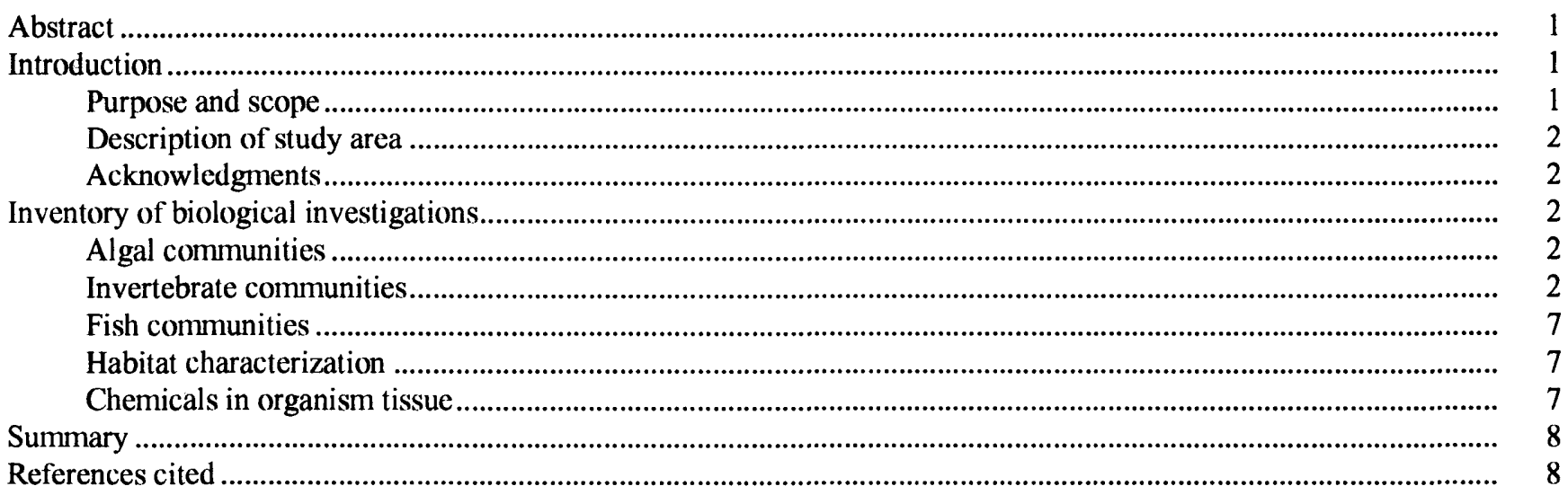

\section{FIGURE}

1. Map showing location of the South Platte River Basin study unit.

\section{TABLE}

1. Literature citations indexed by physiographic province or transition zone and type of biological investigation conducted in the South Platte River Basin

\section{CONVERSION FACTORS}

\begin{tabular}{rll}
\hline Multiply & By & To obtain \\
\hline mile & 1.609 & kilometer \\
square mile & 2.590 & square kilometer \\
\hline
\end{tabular}




\title{
Inventory of Biological Investigations Related To Stream Water Quality in the South Platte River Basin, Colorado, Nebraska, and Wyoming, 1891-1994
}

\author{
By Cathy M. Tate and Jorge R. Ortiz-Zayas
}

\begin{abstract}
An inventory of the biological investigations conducted in the South Platte River Basin from 1891 to 1994 was done as a part of the U.S. Geological Survey's National Water-Quality Assessment (NAWQA) program in the South Platte River Basin. To aid in the sampling design of the biological component of the South Platte NAWQA, sources of water-related studies were compiled from computerized literature searches of biological data bases and by contacting other Federal, State, and local agencies. Biological investigations were categorized by their location in either of two major physiographic provincesthe Southern Rocky Mountains or the Great Plains, or in the transition zone between the mountains and the plains. From this collection of 102 references, five general categories of biological investigations were identified: algae, invertebrates, fish, habitat characterization, and chemicals in organism tissue. The most abundant literature was on studies of invertebrate and fish communities. Invertebrate studies primarily were conducted in the mountain region. There was limited information on algae, invertebrates in the plains region, flood-plain vegetation in the mountains and transition zone, and chemicals in organism tissue.
\end{abstract}

\section{INTRODUCTION}

In 1991, the U.S. Geological Survey implemented the National Water-Quality Assessment (NAWQA) program. The NAWQA program is designed to describe the status of, and trends in, the Nation's surface- and ground-water resources and to provide an understanding of the natural and human factors that affect the quality of these resources (Hirsch and others, 1988; Leahy and others, 1990). The NAWQA program is an integrated approach using physical, chemical, and biological measurements to assess water quality. The biological component includes information on: (1) Trace-element and organic contaminants in bed material and aquatic biota; (2) biological communities (algal, invertebrate, and fish); and (3) stream habitat characterization (Gurtz, 1994).

A major design feature of the NAWQA program is the integration of water-quality information at different areal scales. The principal building blocks of the program are the study-unit investigations on which the national-level assessments are based. In 1991, the South Platte River Basin was among the first 20 NAWQA study units selected for investigation.

The first step to the implementation of the biological component of the South Platte NAWQA program was to examine existing biological information. Examination of existing data provides a historical perspective to biological information about the basin, the strengths and deficiencies of available information, and the implications for water-quality issues.

\section{Purpose and Scope}

This report establishes an inventory of the biological information for the South Platte River Basin from 1891 to 1994. The report also (1) identifies the sources of biological information for the South Platte River Basin, (2) categorizes this information in relation to the biological components of the NAWQA program, and (3) determines the information gaps in the basin. Biological information from 102 references from 1891 to 1994 were identified and divided into five assessment categories related to the biological components of the NAWQA program: (1) Algae, (2) invertebrates, (3) fish, (4) habitat characterization, and (5) chemicals in organism tissue. The category of habitat characterization included studies of flood-plain vegetation and geomorphology. Many of the references in this report are a subset of references compiled from a computerized bibliographic search of 11 data bases using the DIALOG Information Retrieval Service through 1991, as described in detail in Dennehy and 
Ortiz-Zayas (1993). In addition, other agencies, such as the Colorado Division of Wildlife, Colorado Water Resources Research Institute, U.S. Environmental Protection Agency, U.S. Fish and Wildlife Service, National Park Service, Bureau of Reclamation, Great Plains Library, and universities were contacted to amend and update the reference list. Individual scientists conducting biological studies in the South Platte River Basin also were contacted to update the reference list through 1994. Experts in the different categories of biology (algae, invertebrates, fish, habitat characterization, and chemicals in organism tissue) reviewed this bibliography to determine if there were obvious omissions. References include published and unpublished reports and books, master's theses and doctoral dissertations, conference proceedings, and journal articles. Omitted are publications in press, book reviews, and abstracts.

\section{Description of Study Area}

The South Platte River Basin drains about a 24,300-square-mile area and includes parts of three States-Colorado, Nebraska, and Wyoming (fig. 1). There are two major physiographic provinces (Lobeck, 1922), the Southern Rocky Mountains and the Great Plains. The primary river in the basin, the South Platte River, originates in the mountains of central Colorado and flows about $450 \mathrm{mi}$ northeast across the Great Plains to its confluence with the North Platte River in Nebraska. From the mountains to the plains, the South Platte River and its tributaries cross a transitional zone along the foothills. Streams are characterized as cold-water streams in the mountains and as warmwater streams in the plains. A detailed description of the basin environmental setting is reported in Dennehy and others (1993).

\section{Acknowledgments}

The authors wish to thank April Kobayashi and Joyce Dickey, U.S. Geological Survey, for their efforts in conducting a bibliographic search of data bases and retrieval of references. Additionally, we thank John W. Martin and Richard Sojda of the U.S. Fish and Wildlife Service for their assistance in providing additional references missed by the computerized search. We thank Kenneth Bazata, Kevin Bestgen, Boris Kondratieff, Kurt King, and John Woodling for reviewing the bibliography for completeness. We thank K.F. Dennehy, L.F. Carter, and R.M. Goldstein for their critical review of the manuscript.

\section{INVENTORY OF BIOLOGICAL INVESTIGATIONS}

Biological investigations that relate to water quality in the South Platte River Basin were grouped into five categories corresponding to the biological components of the NAWQA program: algae, invertebrates, fish, habitat characterization, and chemicals in organism tissue (table 1). Biological investigations also were categorized according to their site location in the two physiographic provinces or in the transition zone between the mountains and plains because distinct biological communities are associated with the mountain and the plains streams (Dennehy and others, 1993). A general overview of the major biological communities associated with the mountain and plain streams in the South Platte River Basin is reported in Dennehy and others (1993, table 8, p. 676).

\section{Algal Communities}

There were a total of eight investigations referenced between 1974 and 1987 that included algal information (table 1). Six of those studies were located in the mountains, one study was in the mountains and transition zone, and one study was in the plains. Algal investigations included five studies examining the effect of reservoirs on algae (Ward, 1976; Gray and Ward, 1982; Cline and Ward, 1984; Zimmerman and Ward, 1984; Dufford and others, 1987), two studies collecting baseline information on algal communities (Galat and McConnell, 1974; Ward, 1986), and one study examining the effect of highway construction on algae (Cline and others, 1982). There is an information gap for algae throughout the basin, particularly in the plains.

\section{Invertebrate Communities}

There were a total of 43 investigations that included invertebrate information. Seven investigations included sites in the mountains and plains, 26 included sites in the mountains, 3 included sites located in the mountains and transition zone, 1 included sites in the transition zone and plains, and 6 included sites in the plains (table 1). The invertebrate investigations included 27 studies on basic information about invertebrates or baseline information on invertebrate distribution (Mecom, 1972; Galat and McConnell, 1974; Ward, 1975, 1984; Bauman and others, 1977; Kodadek, 1978; Ward and Short, 1978; Molnar and Lavigne, 1979; Short and others, 1980; Short and Ward, 1980a,b; Short, 1983; Ruiter and Lavigne, 1985; 


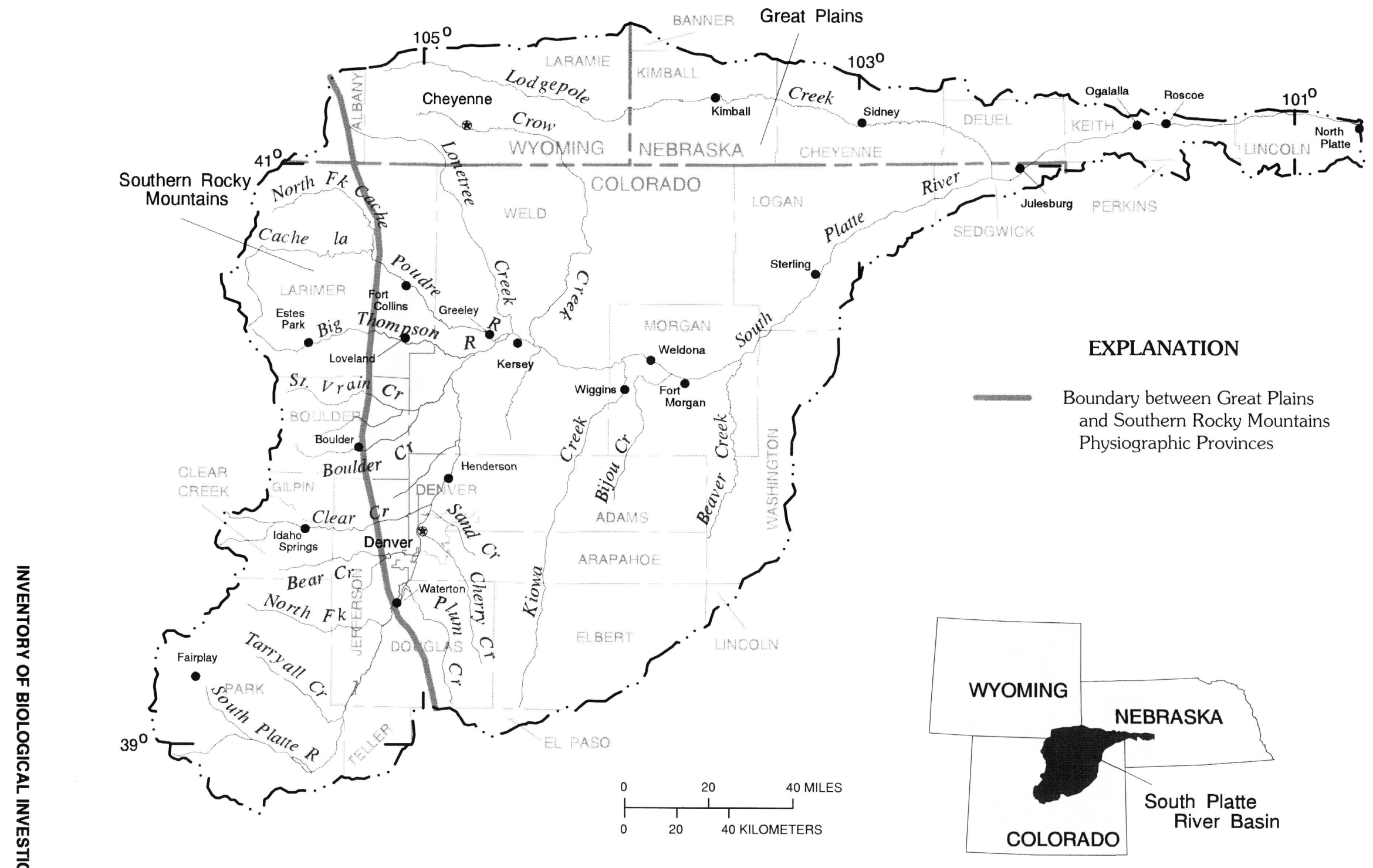

Figure 1. Location of the South Platte River Basin study unit. 
Table 1. Literature citations indexed by physiographic province or transition zone ${ }^{1}$ and type of biological investigation conducted in the South Platte River Basin

\begin{tabular}{|c|c|c|c|c|c|c|c|c|}
\hline \multirow[b]{2}{*}{ Literature citation } & \multicolumn{3}{|c|}{ Location in the basin } & \multicolumn{5}{|c|}{ Biological investigations } \\
\hline & $\begin{array}{l}\text { Southern } \\
\text { Rocky } \\
\text { Mountains }\end{array}$ & $\begin{array}{l}\text { Transition } \\
\text { zone }\end{array}$ & $\begin{array}{l}\text { Great } \\
\text { Plains }\end{array}$ & $\begin{array}{l}\text { Algal } \\
\text { commu- } \\
\text { nities }\end{array}$ & $\begin{array}{c}\text { Inverte- } \\
\text { brate } \\
\text { commu- } \\
\text { nities }\end{array}$ & $\begin{array}{l}\text { Fish } \\
\text { commu- } \\
\text { nities }\end{array}$ & $\begin{array}{c}\text { Habitat } \\
\text { character- } \\
\text { Ization }\end{array}$ & $\begin{array}{l}\text { Chemicals } \\
\text { in } \\
\text { organism } \\
\text { tissue }\end{array}$ \\
\hline Anderson and Nehring (1985) & $\mathrm{X}$ & & & & & $\mathrm{X}$ & & \\
\hline Andrews (1970) & $\mathrm{X}$ & & $\mathrm{x}$ & & & $\mathrm{x}$ & & \\
\hline Bauman and others (1977) & $\mathrm{x}$ & & & & $\mathrm{X}$ & & & \\
\hline Baxter and Simon (1970) & & $\mathrm{X}$ & $\mathrm{X}$ & & & $\mathrm{x}$ & & \\
\hline Beckman (1952) & $\mathrm{x}$ & & $\mathrm{x}$ & & & $\mathrm{x}$ & & \\
\hline Bergey and Ward (1989) & $\mathrm{x}$ & & & & $\mathrm{X}$ & & & \\
\hline Bestgen (1989) & & $\mathrm{x}$ & & & & $\mathrm{x}$ & & \\
\hline Bestgen and Culver (1985) & & & $\mathrm{X}$ & & & $\mathrm{x}$ & & \\
\hline $\begin{array}{l}\text { Bestgen and Fausch } \\
\text { (written commun., 1993a) }\end{array}$ & & $\mathrm{X}$ & & & & $\mathrm{x}$ & & \\
\hline $\begin{array}{l}\text { Bestgen and Fausch } \\
\text { (written commun., 1993b) }\end{array}$ & & $\mathrm{x}$ & $\mathrm{x}$ & & & $\mathrm{x}$ & & \\
\hline Boaze $(1977 a)$ & $\mathrm{X}$ & & & & & $\mathrm{x}$ & & \\
\hline Boaze (1977b) & $\mathrm{X}$ & & & & & $\mathrm{x}$ & & \\
\hline Canton and others (1984) & $\mathrm{X}$ & & & & $\mathrm{x}$ & $\mathrm{X}$ & & \\
\hline $\begin{array}{l}\text { Chadwick \& Associates, Inc. } \\
\text { (1986) }\end{array}$ & $\mathrm{X}$ & & $\mathrm{x}$ & & $\mathrm{x}$ & $\mathrm{x}$ & & \\
\hline Chart and others (1987) & $\mathrm{X}$ & $\mathrm{X}$ & & & & $\mathrm{x}$ & & \\
\hline Christy (1972a) & & & $\mathrm{X}$ & & & & $\mathrm{X}$ & \\
\hline Christy (1972b) & & & $\mathrm{X}$ & & & & $\mathrm{X}$ & \\
\hline Cline and others (1982) & $\mathrm{x}$ & & & $\mathrm{X}$ & $\mathrm{x}$ & & & \\
\hline Cline and Ward (1984) & $\mathrm{x}$ & & & $\mathrm{x}$ & $\mathrm{x}$ & & & \\
\hline Cockerell (1908) & $\mathrm{x}$ & & & & & $\mathrm{x}$ & & \\
\hline Crouch (1979) & & & $\mathrm{x}$ & & & & $\mathrm{x}$ & \\
\hline Culver and Bestgen (1983) & $\mathrm{X}$ & & & & & $\mathrm{X}$ & & \\
\hline Culver and Bestgen (1986) & $\mathrm{x}$ & & & & & $\mathrm{X}$ & & \\
\hline Deacon and Vaught (1993) & $\mathrm{x}$ & $\mathrm{x}$ & & & $\mathrm{x}$ & & & \\
\hline DeWeese and others (1993) & & & $\mathrm{x}$ & & & & & $\mathrm{x}$ \\
\hline Dufford and others (1987) & $\mathrm{x}$ & & & $\mathrm{x}$ & & & & \\
\hline Eder and Carlson (1977) & & & $\mathrm{X}$ & & & $\mathrm{X}$ & & \\
\hline Ellis (1914) & $\mathrm{X}$ & & $\mathrm{x}$ & & & $\mathrm{X}$ & & \\
\hline Eschner and others (1983) & & & $\mathrm{x}$ & & & & $\mathrm{X}$ & \\
\hline Evans (1988) & $\mathrm{X}$ & & $\mathrm{x}$ & & $\mathrm{X}$ & & & \\
\hline Friedman (1993) & & & $x$ & & & & $\mathrm{x}$ & \\
\hline Galat and McConnell (1974) & & & $\mathrm{x}$ & $\mathrm{x}$ & $\mathrm{x}$ & & & \\
\hline Goettl (1980) & & & $\mathrm{x}$ & & & $\mathrm{x}$ & & \\
\hline Goettl (1981) & & & $\mathrm{x}$ & & & $\mathrm{x}$ & & \\
\hline Goettl (1982) & & & $\mathrm{x}$ & & & $\mathrm{x}$ & & \\
\hline Gray and Ward (1982) & $\mathrm{x}$ & & & $\mathrm{x}$ & $\mathrm{X}$ & & & \\
\hline Hendricks (1950) & $\mathrm{x}$ & & $\mathrm{x}$ & & & $\mathrm{X}$ & & \\
\hline
\end{tabular}


Ta le 1. Literature citations indexed by physiographic province or transition zone $e^{1}$ and type of biological investigation conducted in the South Platte River Basin--Continued

\begin{tabular}{|c|c|c|c|c|c|c|c|c|}
\hline \multirow[b]{2}{*}{ Literature citation } & \multicolumn{3}{|c|}{ Location in the basin } & \multicolumn{5}{|c|}{ Biological investigations } \\
\hline & $\begin{array}{l}\text { Southern } \\
\text { Rocky } \\
\text { Mountains }\end{array}$ & $\begin{array}{c}\text { Transition } \\
\text { zone }\end{array}$ & $\begin{array}{l}\text { Great } \\
\text { Plains }\end{array}$ & $\begin{array}{l}\text { Algal } \\
\text { commu- } \\
\text { nities }\end{array}$ & $\begin{array}{l}\text { Inverte- } \\
\text { brate } \\
\text { commu- } \\
\text { nities }\end{array}$ & $\begin{array}{l}\text { Flsh } \\
\text { commu- } \\
\text { nities }\end{array}$ & $\begin{array}{l}\text { Habitat } \\
\text { character- } \\
\text { ization }\end{array}$ & $\begin{array}{c}\text { Chemicals } \\
\text { in } \\
\text { organism } \\
\text { tissue }\end{array}$ \\
\hline Hepworth (1973) & & & $\mathrm{X}$ & & & $\mathrm{X}$ & & \\
\hline Hermann and others (1986) & $X$ & & $\mathrm{X}$ & & $\mathrm{X}$ & & & \\
\hline Jackson (1972) & & & $\mathrm{X}$ & & & & $\mathrm{X}$ & \\
\hline Jackson and Lindauer (1978) & & & $\mathrm{X}$ & & & & $\mathrm{X}$ & \\
\hline Johnson (1942) & & & $\mathrm{X}$ & & & $\mathrm{X}$ & & \\
\hline Johnson (1994) & & & $\mathrm{X}$ & & & & $\mathrm{X}$ & \\
\hline Jordan (1891) & $\mathrm{X}$ & & $\mathrm{X}$ & & & $X$ & & \\
\hline Juday (1904) & $X$ & & $X$ & & & $X$ & & \\
\hline Juday (1905) & $X$ & & $\mathrm{X}$ & & & $X$ & & \\
\hline Knopf and Scott (1990) & & & $\mathrm{X}$ & & & & $\mathrm{X}$ & \\
\hline Kodadek (1978) & $X$ & $X$ & & & $\mathrm{X}$ & & & \\
\hline Kondratieff and others (1990) & $\mathrm{X}$ & & & & $\mathrm{X}$ & & & \\
\hline Lehnertz (1991) & $X$ & & & & $X$ & $X$ & & \\
\hline Lewis and Saunders (1985) & & & $\mathrm{X}$ & & & $X$ & & \\
\hline $\operatorname{Li}(1968)$ & $X$ & & $\mathrm{X}$ & & & $\mathrm{X}$ & & \\
\hline Lindauer (1983) & & & $\mathrm{X}$ & & & & $\mathrm{X}$ & \\
\hline Lowe and others (1985) & & & $X$ & & & & & $\mathrm{X}$ \\
\hline Marmonier and Ward (1990) & $X$ & & $\mathrm{X}$ & & $X$ & & & \\
\hline Marshall (1973) & $\mathrm{X}$ & & & & & $\mathrm{X}$ & & \\
\hline McCafferty and others (1993) & $\mathrm{X}$ & & $\mathrm{X}$ & & $\mathrm{X}$ & & & \\
\hline Mecom (1972) & $\mathrm{X}$ & & & & $\mathrm{X}$ & & & \\
\hline Molnar and Lavigne (1979) & & & $\mathrm{X}$ & & $\mathrm{X}$ & & & \\
\hline Platania (1990) & & $X$ & & & & $X$ & & \\
\hline Platania and others (1986) & & & $\mathrm{X}$ & & & $\mathrm{X}$ & & \\
\hline Propst (1982) & $\mathrm{X}$ & & $\mathrm{X}$ & & & $\mathrm{X}$ & & \\
\hline Propst and Carlson (1986) & $X$ & & $\mathrm{X}$ & & & $\mathrm{X}$ & & \\
\hline Propst and Carlson (1989) & & $\mathrm{X}$ & & & & $\mathrm{X}$ & & \\
\hline Rader and Ward (1987a) & $\mathrm{X}$ & & & & $\mathrm{X}$ & & & \\
\hline Rader and Ward (1987b) & $\mathrm{X}$ & & & & $\mathrm{X}$ & & & \\
\hline Reid and Bock (1978) & $\mathrm{X}$ & & & & & & $\mathrm{X}$ & \\
\hline Rosenlund and Stevens (1988) & $\mathrm{X}$ & & & & & $\mathrm{X}$ & & \\
\hline Rosenlund and Stevens (1990) & $\mathrm{X}$ & & & & & $\mathrm{X}$ & & \\
\hline Ruby and others (1991) & & & $\mathrm{X}$ & & $\mathrm{X}$ & & & \\
\hline Ruiter (1990) & $\mathrm{X}$ & & $\mathrm{X}$ & & $\mathrm{X}$ & & & \\
\hline Ruiter and Lavigne (1985) & & & $X$ & & $\mathrm{X}$ & & & \\
\hline Schmitt and others (1990) & & & $\mathrm{X}$ & & & & & $\mathrm{X}$ \\
\hline Schrader (1989) & & & $\mathrm{X}$ & & & $\mathrm{X}$ & & \\
\hline Sedgwick and Knopf (1989) & & & $\mathrm{X}$ & & & & $\mathrm{X}$ & \\
\hline Short (1983) & $\mathrm{X}$ & & & & $\mathrm{X}$ & & & \\
\hline Short and others (1980) & $\mathrm{X}$ & & & & $\mathrm{X}$ & & & \\
\hline Short and Ward (1980a) & $\mathrm{X}$ & & & & $\mathrm{X}$ & & & \\
\hline
\end{tabular}


Table 1. Literature citations indexed by physiographic province or transition zone ${ }^{1}$ and type of biological investigation conducted in the South Platte River Basin--Continued

\begin{tabular}{|c|c|c|c|c|c|c|c|c|}
\hline \multirow[b]{2}{*}{ Literature citation } & \multicolumn{3}{|c|}{ Location in the basin } & \multicolumn{5}{|c|}{ Biological investigations } \\
\hline & $\begin{array}{l}\text { Southern } \\
\text { Rocky } \\
\text { Mountains }\end{array}$ & $\begin{array}{l}\text { Transition } \\
\text { zone }\end{array}$ & $\begin{array}{l}\text { Great } \\
\text { Plains }\end{array}$ & $\begin{array}{c}\text { Algal } \\
\text { commu- } \\
\text { nities }\end{array}$ & $\begin{array}{l}\text { Inverte- } \\
\text { brate } \\
\text { commu- } \\
\text { nities }\end{array}$ & $\begin{array}{c}\text { Fish } \\
\text { commu- } \\
\text { nities }\end{array}$ & $\begin{array}{l}\text { Habitat } \\
\text { character- } \\
\text { ization }\end{array}$ & $\begin{array}{c}\text { Chemicals } \\
\text { in } \\
\text { organism } \\
\text { tissue }\end{array}$ \\
\hline Short and Ward (1980b) & $\mathrm{X}$ & & & & $\mathrm{X}$ & & & \\
\hline Snyder and Miller (1991) & & & $\mathrm{X}$ & & & & $\mathrm{X}$ & \\
\hline Stevens and Rosenlund (1990) & $\mathrm{X}$ & & & & & $\mathrm{X}$ & & \\
\hline $\begin{array}{l}\text { U.S. Environmental Protection } \\
\text { Agency (1972) }\end{array}$ & & & $X$ & & $\mathrm{X}$ & & & \\
\hline $\begin{array}{l}\text { U.S. Environmental Protection } \\
\text { Agency (1992) }\end{array}$ & & & $\mathrm{X}$ & & & & & $\mathrm{X}$ \\
\hline $\begin{array}{l}\text { Voelz and others } \\
\text { (written commun., 1993) }\end{array}$ & & $X$ & $\mathrm{X}$ & & $\mathrm{X}$ & & & \\
\hline Walsh and others (1977) & & & $\mathrm{X}$ & & & & & $\mathrm{X}$ \\
\hline Ward (1974) & $\mathrm{X}$ & & & & $X$ & & & \\
\hline Ward (1975) & $\mathrm{X}$ & & & & $\mathrm{X}$ & & & \\
\hline Ward (1976) & $X$ & & & $\mathrm{X}$ & $\mathrm{X}$ & & & \\
\hline Ward (1981) & $\mathrm{X}$ & & & & $\mathrm{X}$ & & & \\
\hline Ward (1982) & $\mathrm{X}$ & & & & $\mathrm{X}$ & & & \\
\hline Ward (1984) & $\mathrm{X}$ & & & & $\mathrm{X}$ & & & \\
\hline Ward (1986) & $\mathrm{X}$ & $\mathrm{X}$ & & $X$ & $\mathrm{X}$ & & & \\
\hline Ward (1987) & $\mathrm{X}$ & & & & $\mathrm{X}$ & & & \\
\hline Ward and Berner (1980) & $\mathrm{X}$ & & & & $\mathrm{X}$ & & & \\
\hline Ward and Kondratieff (1992) & $\mathrm{X}$ & & & & $\mathrm{X}$ & & & \\
\hline Ward and Short (1978) & $\mathrm{X}$ & & & & $\mathrm{X}$ & & & \\
\hline Williams (1978) & & & $\mathrm{X}$ & & & & $\mathrm{X}$ & \\
\hline Wiltzius (1981) & $\mathrm{X}$ & & $\mathrm{X}$ & & & $\mathrm{X}$ & & \\
\hline Woodling (1977) & & & $\mathrm{X}$ & & $\mathrm{X}$ & $\mathrm{X}$ & & \\
\hline Woodling (1985) & $\mathrm{X}$ & & $X$ & & & $\mathrm{X}$ & & \\
\hline Wu (1989) & $\mathrm{X}$ & & $\mathrm{X}$ & & $\mathrm{X}$ & & & \\
\hline Zimmerman and Ward (1984) & $\mathrm{X}$ & & & $\mathrm{X}$ & $\mathrm{X}$ & & & \\
\hline
\end{tabular}

\footnotetext{
${ }^{1}$ The transition zone is located between the Southern Rocky Mountains and Great Plains physiographic province.
} 


\section{SUMMARY}

Quantitative basinwide evaluations of the biological communities, as related to water quality in the South Platte River Basin, are difficult to make using existing studies because data were collected and analyzed by a variety of methods, and the studies were limited in scope. Examination of the data contained in these biological studies, however, does provide valuable information for the implementation of the biological component of the NAWQA program in the South Platte River Basin.

Studies of invertebrate communities in the mountains and fish communities throughout the basin were the most common biological investigations reported for the South Platte River Basin: Four biological information gaps for the South Platte River Basin were identified: (1) Algal information throughout the basin, (2) invertebrate information for the plains, (3) flood-plain-vegetation information for the mountains and in the transition zone, and (4) information about chemical contaminants in organism tissue basinwide.

\section{REFERENCES CITED}

Anderson, R.M., and Nehring, R.B., 1985, Impacts of stream discharge on trout rearing habitat and trout recruitment in the South Platte River, Colorado, in Olson, F.W., and others, eds., Proceedings of symposium on small hydropower and fisheries: Bethesda, American Fisheries Society, p. 59-64.

Andrews, A.K., 1970, The distribution and life history of the fathead minnow (Pimephales promelas Rafinesque) in Colorado: Fort Collins, Colorado State University, Ph.D. dissertation, $131 \mathrm{p}$.

Bauman, R.W., Gaufin, A.R., and Surdick, R.F., 1977, The stonefiles (Plecoptera) of the Rocky Mountains: American Entomological Society Memoirs, no. 31, 208 p.

Baxter, G.T., and Simon, J.R., 1970, Wyoming fishes: Cheyenne, Wyoming Game and Fish Department, $168 \mathrm{p}$.

Beckman, W.C., 1952, A guide to the fishes of Colorado: Boulder, University of Colorado Museum Leaflet 11, $110 \mathrm{p}$.

Bergey, E.A., and Ward, J.V., 1989, Upstream-downstream movements of aquatic invertebrates in a Rocky Mountain stream: Hydrobiologia, v. 185, no. 1, p. 71-82.

Bestgen, K.R., 1989, Distribution and notes on the biology of Phoxinus eos (Cyprinidae) in Colorado: Southwestern Naturalist, v. 34, no. 2, p. 225-231.

Bestgen, K.R., and Culver, S.R., 1985, Survey of the fishes of the Plum Creek drainage, Colorado, 1985: Fort Collins, Colorado Division of Wildlife, Northeast Regional Fisheries, $51 \mathrm{p}$.
Boaze, J.L., 1977a, An evaluation of the South Platte River fish population between Deckers and South Platte, Colorado: Salt Lake City, U.S. Fish and Wildlife Service, $30 \mathrm{p}$.

Boaze, J.L., 1977b, An evaluation of the fish population, North Fork of the South Platte River: Salt Lake City, U.S. Fish and Wildlife Service, 18 p.

Canton, S.P., Cline, L.D., Short, R.A., and Ward, J.V., 1984, The macroinvertebrates and fish of a Colorado stream during a period of fluctuating discharge: Freshwater Biology, v. 14, no. 3, p. 311-316.

Chadwick \& Associates, Inc., 1986, Aquatic baseline, metropolitan Denver water supply systemwide/sitespecific environmental impact statement: Denver, unpublished report for the Denver Water Board, [variously paged]. (Available from Denver Water Board, Denver, CO 80523.)

Chart, Thomas, Gillihan, Scott, and Krieger, Douglas, 1987, Inventory of the nongame fish of Saint Vrain Creek drainage, Colorado in 1986, Fort Collins, Colorado Di $\mathrm{n}$ of Wildlife, Northeast Regional Fisheries, 57.

Christy, Stephen, 1972a, Plant communities of the South Platte River floodplain in Colorado: Journal of Colorado-Wyoming Academy of Sciences, v. 7, no. 2-3, p. 31.

Christy, Stephen, 1972b, Woody vegetation along the South Platte River in northeastern Colorado: Journal of Colorado-Wyoming Academy of Sciences, v. 7 , no. 2-3, p. 106.

Cline, L.D., Short, R.A., and Ward, J.V., 1982, The influence of highway construction on the macroinvertebrates and epilithic algae of a high mountain stream: Hydrobiologia, v. 96, no. 2, p. 149-159.

Cline, L.D., and Ward, J.V., 1984, Biological and physiochemical changes downstream from construction of a subalpine reservoir, Colorado, USA, in Lillehammer, Albert, and Salveit, S.J., eds., Regulated rivers: Oslo, Norway, University of Oslo Press, p. 233-243.

Cockerell, T.D.A., 1908, The fishes of the Rocky Mountain region: University of Colorado Studies, v. 5, no. 3, p. $159-178$.

Crouch, G.L., 1979, Changes in the vegetation complex of a cottonwood ecosystem on the South Platte River: Great Plains Agricultural Council Publication 19, p. 19-22.

Culver, S.R., and Bestgen, K.R., 1983, Greenback cutthroat trout recovery project, 1982 progress report:

Fort Collins, Colorado Division of Wildlife, Northeast Regional Fisheries, $74 \mathrm{p}$.

Culver, S.R., and Bestgen, K.R., 1986, Greenback cutthroat trout recovery project, 1985 progress report: Fort Collins, Colorado Division of Wildlife, Northeast Regional Fisheries, $37 \mathrm{p}$. 
and corrections to the distribution and records of Colorado Trichoptera: Entomological News, v. 101, no. 2, p. 88-92.

Ruiter, D.E., and Lavigne, R.L., 1985, Distribution of Wyoming trichoptera: University of Wyoming Agricultural Experiment Station Publication SM 47, 102 p.

Schmitt, C.J., Zajicek, J.L., and Petermen P.H., 1990, National Contaminant Biomonitoring Program-Residues of organochlorine chemicals in U.S. freshwater fish, 1976-1984: Archives of Environmental Contamination and Toxicology, v. 19, no. 5, p. 748-781.

Schrader, L.H., 1989, Use of the index of biotic integrity to evaluate fish communities in western Great Plains streams: Fort Collins, Colorado State University, Master's thesis, $120 \mathrm{p}$.

Sedgwick, J.A., and Knopf, F.L., 1989, Demography, regeneration, and future projections for a bottomland cottonwood community, in Sharitz, R.R., and Gibbons, J.W., eds., Freshwater wetlands and wildlife: U.S. Department of Energy Symposium Series 61, p. 249-266. [Available from National Technical Information Service, Springfield, Va.]

Short, R.A., 1983, Food habits and dietary overlap among six stream collector species: Freshwater Invertebrate Biology, v. 2, no. 2, p. 132-138.

Short, R.A., Canton, S.P., and Ward, J.V., 1980, Detrital processing and associated macroinvertebrates in a Colorado mountain stream: Ecology, v. 61, no. 4, p. 727-732.

Short, R.A, and Ward, J.V., 1980a, Life history and production of Skwala parallela (Frison) (Plecoptera: Perlodidae) in a Colorado montane stream: Hydrobiologia, v. 69 , no. 3 , p. $273-275$.

Short, R.A., and Ward, J.V., 1980b, Macroinvertebrates of a Colorado high mountain stream: Southwestern Naturalist, v. 25 , no. 2 , p. 23-32.

Snyder, W.D., and Miller, G.C., 1991, Changes in plains cottonwoods along the Arkansas and South Platte Rivers, eastern Colorado: Prairie Naturalist, v. 23, no. 3, p. 165-176.

Stevens, D.R., and Rosenlund, B.D., 1990, Greenback cutthroat trout restoration in Rocky Mountain National Park: Fish and Coastal Wetlands Research, v. 6, p. 104-118.

U.S. Environmental Protection Agency, 1972, Water quality investigations in the South Platte River Basin, Colorado, 1971-1972: Denver, Colorado, 73 p., plus appendices.

U.S. Environmental Protection Agency, 1992, National study of chemical residues in fish (v. I and II): Standards and Applied Division Report EPA 823-R-92$008 \mathrm{a}$ and $\mathrm{b}, 166 \mathrm{p}$., plus appendices.

Walsh, D.F., Berger, B.L., and Bean, J.R., 1977, Mercury, arsenic, lead, cadmium, and selenium residues in fish,
1971-1976, National Pesticide Monitoring Program: Pesticide Monitoring Journal, v. 11, no. 1, p. 5-34.

Ward, J.V., 1974, A temperature-stressed stream ecosystem below a hypolimnial release mountain reservoir: Archiv fur Hydrobiologie, v. 74, no. 2, p. 247-275.

Ward, J.V., 1975, Bottom fauna-substrate relationships in a northern Colorado trout stream, 1945 and 1974: Ecology, v. 46, no. 6, p. 1429-1434.

Ward, J.V., 1976, Comparative limnology of differentially regulated sections of a Colorado mountain river: Archive fur Hydrobiologie, v. 78, no. 3, p. 319-342.

Ward, J.V.,1981, Altitudinal distribution and abundance of Trichoptera in a Rocky Mountain stream: Series Entomologica, v. 20, p. 375-382.

Ward, J.V., 1982, Altitudinal zonation of Plecoptera in a Rocky Mountain stream: Aquatic Insects, v. 4, no. 2, p. 105-110.

Ward, J.V., 1984, Diversity patterns exhibited by the Plecoptera of a Colorado mountain stream: Annales de Limnologie, v. 20, no. 1-2, p. 123-128.

Ward, J.V., 1986, Altitudinal zonation in a Rocky Mountain stream: Archive fur Hydrobiologie, Supplement, v. 74, no. 2, p. 133-199.

Ward, J.V., 1987, Trichoptera of regulated Rocky Mountain streams: Series Entomologica, v. 39, p. 375-380.

Ward, J.V., and Berner, L., 1980, Abundance and altitudinal distribution of Ephemeroptera in a Rocky Mountain stream, in Flannagan, J.F., and Marshall, K.E., eds., Advances in Ephemeroptera biology: New York, Plenum, p. 169-178.

Ward, J.V., and Kondratieff, B.C., 1992, An illustrated guide to the mountain stream insects of Colorado: Niwot, University Press of Colorado, $191 \mathrm{p}$.

Ward, J.V., and Short, R.A., 1978, Macroinvertebrate community structure of four special lotic habitats in Colorado: Internationale Vereinigung fur Theoretische und Angewandte Limnologie, v. 20, no. 2, p. 1382-1387.

Williams, G.P., 1978, Historical perspective of the Platte Rivers in Nebraska and Colorado, in Graul, W.D., and Bissell, S.J., eds., Lowland river and stream habitat in Colorado-A symposium (Greeley, Colorado, October 4-5, 1978): Denver, Colorado Chapter of The Wildlife Society and Colorado Audubon Council, p. $11-40$.

Wiltzius, W.J., 1981, Compendium of introduction dates and State and Federal annual stocking of various fishes in Colorado, 1872-1978: Fort Collins, Colorado Division of Wildlife, $94 \mathrm{p}$.

Woodling, John, 1977, Effects of water discharges from Great Western sugar mills at Ovid, Sterling, and Fort Morgan, Colorado, and the Sterling Wastewater Treatment Facility in the South Platte River, 1976-1977: Denver, Colorado Department of Health, Water Quality Division, 37 p. 
Woodling, John, 1985, Colorado's little fish, a guide to the minnows and other lesser known fishes in the State of Colorado: Denver, Colorado Division of Wildlife, Department of Natural Resources, $77 \mathrm{p}$.

Wu, Shi-Kuei, 1989, Colorado freshwater mollusks: University of Colorado Museum, Natural History Inventory of Colorado 11, $117 \mathrm{p}$.
Zimmerman, H.J., and Ward, J.V., 1984, A survey of regulated streams in the Rocky Mountains of Colorado, in Lillehammer, Albert, and Salveit, S.J., eds., Regulated rivers: Oslo, Norway, University of Oslo Press, p. 251-262. 